\title{
Aspek Geografis Tapak PLTN di Kawasan Bintan - Barelang
}

\author{
Edwaren Liun ${ }^{\star 1}$, Dharu Dewi ${ }^{1}$, Arum Puni Riyanti ${ }^{1}$ dan Hadi Suntoko ${ }^{1}$ \\ ${ }^{1}$ Pusat Kajian Sistem Energi Nuklir, BATAN, Jl. Kuningan Barat, Jakarta, Indonesia
}

\begin{tabular}{l}
\hline INFORMASI ARTIKEL \\
\hline Riwayat Artikel: \\
Diterima: \\
31 Oktober 2019 \\
Diterima dalam bentuk revisi: \\
02 Desember 2019 \\
Disetujui: \\
09 Januari 2020
\end{tabular}

Kata kunci: aspek geografis, kawasan Bintan - Barelang, pengembangan sistem kelistrikan, ekonomis, efisien, PLTN, HVDC.

\begin{abstract}
ABSTRAK
ASPEK GEOGRAFIS TAPAK PLTN DI KAWASAN BINTAN - BARELANG. Wilayah Bintan Barelang merupakan bagian dari paparan kontinental, terdiri atas pulau-pulau yang tersebar sebagai sisa-sisa erosi atau penyusutan dari daratan pra Tersier yang membentang dari semenanjung Malaysia/ pulau Singapore. Posisi geografisnya berada pada jalur transportasi laut yang padat, sehingga ia memiliki potensi peran yang signifikan terhadap berbagai sektor ekonomi. Salah satunya adalah sektor kelistrikan yang hingga saat ini pemenuhan kebutuhannya belum berada pada bauran energi yang ideal karena masih didominasi oleh bahanbakar minyak. Sementara untuk sektor transportasi di kawasan Asia Tenggara akan membuat sektor listrik memainkan peran lebih banyak di masa mendatang yang membutuhkan berbagai potensi sumberdaya energi untuk pembangkit listrik. Aktifitas dan pertumbuhan ekonomi mendorong pertumbuhan permintaan listrik yang relatif tinggi di kawasan regional Bintan - Barelang sehingga akan melibatkan sistem kelistrikannya dalam wacana Asean Power Grid. Makalah ini bertujuan untuk menguraikan perspektif ke depan sistem energi dalam kaitannya untuk memenuhi permintaan di sektor transportasi serta meramalkan indikator yang terkait permintaan energi transportasi selama empat dekade ke depan. Metode yang digunakan dalam kajian ini adalah penelusuran pustaka dari berbagai sumber yang relevan. Hasil yang diperoleh dari kajian ini nadalah bahwa posisi geografis Kawasan Bintan - Barelang memiliki potensi pengembangan Pembangkit Listrik Tenaga Nuklir yang berwawasan regional terhadap kawasan sekitarnya khususnya Asia Tenggara yang ekonominya semakin didominasi oleh sektor jasa dan industri.
\end{abstract}

\begin{abstract}
GEOGRAPHICAL ASPECT OF NPP SITES IN BINTAN - BARELANG AREA. The Bintan Barelang region is part of the continental shelf, consisting of islands scattered as remnants of erosion or depreciation from the pre-Tertiary lands stretching from the Malaysian peninsula/ Singapore island. Its geographical position is on a dense sea transportation route, so it has a significant potential role in various economic sectors. One of them is the electricity sector, which until now has not met its ideal energy mix because it is still dominated by oil fuel. Meanwhile, the transportation sector in the Southeast Asia region will make the electricity sector play a greater role in the future that requires a variety of potential energy resources for electricity generation. Economic activity and growth are driving the growth of electricity demand which is relatively high in the Bintan - Barelang region so that it will involve its electricity system in the Asean Power Grid discourse. This paper aims to improve the perspective of the future energy system in relation to meeting the demand in the transportation sector and forecast indicators related to energy demand for transportation for the next four decades. The method used in this study is literature search from various relevant sources. The results obtained from this study are that the geographical position of the Bintan - Barelang region has the potential to develop a Nuclear Power Plant with a regional perspective on the surrounding region, especially Southeast Asia, whose economy is increasingly dominated by the service and industrial sectors.
\end{abstract}

\section{PENDAHULUAN}

Pulau Batam berada dalam satu gugusan yang tersambung dengan tiga pulau lainnya yakni Rempang, Galang dan Galang Baru di Wilayah Kepulauan Riau. Nama Batam banyak disebut dalam catatan perjalanan bangsa asing dan dokumen sejarah, termasuk dalam Traktat London 1824 dan dokumen Kerajaan RiauLingga. Berdasarkan catatan China, Batam dan

*Penulis korespondensi.

E-mail: edwaren@batan.go.id pulau sekitarnya sudah dihuni manusia sejak 231 M sebagaimana Temasek (Singapura) yang pada masa itu masih disebut Pulau Ujung (karena berada di ujung Tanah Semenanjung)[1]. Pesisir Kepulauan Batam dihuni oleh Suku Laut atau disebut juga Orang Selat, sedangkan didaratan (hutan belantara) dihuni suku pedalaman seperti Suku Sakai dan Suku Jakun. Kawasan Kepulauan Riau dan Tanah Semenanjung, termasuk Kepulauan Batam, pernah menjadi wilayah Kerajaan Melayu Singapura, Kemaharajaan Melayu Malaka, Kemaharajaan Melayu (Johor, Riau, 
Lingga, Pahang dan Seluruh Daerah Taklukannya) dan Kerajaan Riau-Lingga[2]. Pada awal Kemaharajaan Melayu (pascaruntuhnya Melaka), kepulauan Batam menjadi wilayah langlang laut (pengawalan) Hang Nadim. Lakasamana Melayu berkhidmat sejak masa Sultan Mahmud Syah I dan Sultan Alauddin Riayat Syah II itu diberikan amanah sebagai Raja Laut atau Langlang Laut yang bertanggung-jawab membendung pengaruh bangsa asing (terutama Portugis) di kepulauan Melayu. Kepulauan Melayu dimaksud termasuk Pulau Batam dan sekitarnya. Konon nama Batam berasal dari kata Batang karena hampir seluruh pantai Batam yang menghadap ke laut Cina selatan ditumbuhi batang pohon jenis tertentu yang khas. Pohon tersebut dibutuhkan oleh para pelaut dan sering singgah di pulau Batam untuk mengambilnya. Selain itu terdapat juga versi lain cerita nama Pulau Batam berasal dari "Batang" yang berarti "jembatan" atau "jalur" penghubung antar pulau Bintang (Bintan), Bulang (bulan), Lingga, dan pulaupulau lainnya ke Temasik (Singapura) dan Johor. Versi lain ada yang menyebutkan dari nama perkampungan terawal di Batam, yaitu "Batuampar" yang disingkat namanya menjadi "Batam".[1]

Selama lebih dari tiga dasawarsa belakangan ini Wilayah Batam dan sekitarnya telah mengalami perkembangan yang signifikan. Tingginya laju transaksi barang dan jasa telah membuat Batam menjadi salah satu kota penting di Selat Malaka. Tercatat bahwa antara tahun 2010 - 2017 PRDB kota Batam mengalami pertumbuhan rata-rata $6,6 \%$ per tahun. [3]

Begitu pentingnya posisi kawasan Pulau Batam akhir-akhir ini kiranya perlu mendapat perhatian khusus terkait dengan peran di bidang energi di masa yang akan datang. Untuk itu makalah ini bertujuan menguraikan sejauh mana potensi kawasan Bintan Barelang dan sekitarnya dari berbagai aspek penggunaan PLTN sebagai salah satu sumber energi listrik bagi kawasan sekitarnya meliputi pulau-pulau Bintan, Rempang, Galang dan lainnya termasuk Singapura.

\section{DATA DAN ASUMSI}

\subsection{Perkembangan Bintan - Barelang dan sekitarnya}

Sebagai wilayah yang bersentuhan dengan aktivitas ekonomi negara jiran Singapura dan Malaysia, Batam mengandung fungsi strategis dari aspek geografisnya. Jarak antara Batam dan Singapura yang hanya $\pm 13 \mathrm{~km}$, dan dapat mengadakan sistem interkoneksi kelistrikan baik dengan sistem AC maupun sistem DC untuk saling memenuhi kebutuhan secara bilateral.

Kawasan pulau-pulau Batam Rempang, Galang yang dikenal dengan sebutan Barelang, bersama Pulau Bintan di mana terletak ibukota Provinsi Kepulauan Riau, adalah salah satu kawasan pertumbuhan strategis nasional yang bersinggunggan secara langsung dengan kawasan industri negara jiran Singapura dan Malaysia.

Di bawah Pemerintahan Republik Indonesia Pembangunan Pulau Batam berawal dengan membentuk Badan Pimpinan Daerah Industri (Badan Penguasa) dan bertanggung jawab kepada Presiden[4], melalui Kepres No. 41 tahun 1973 tanggal 22 November 1973, Pemerintah RI menetapka bahwa seluruh wilayah Pulau Batam dinyatakan sebagai daerah industri.

Pada tanggal 26 Agustus 1974 pemerintah menunjuk beberapa lokasi di Sekupang Batu Ampar dan Kabil di Pulau Batam sebagai Bonded Ware House dan menunjuk PT. Persero Batam sebagai penguasa Bonded Ware House. [2]

Dengan hamparan kepulauan yang terletak antara Selat Malaka dan Laut Natuna, dan antara Pulau Sumatera dan Semenanjung Malaysia dan Singapura, kawasan ini memiliki posisi geografis yang strategis terhadap kawasan di sekitarnya. Berbeda dari Singapura yang hampir menyerpai setengah lingkaran, kawasan Barelang membujur sepanjang terdiri dari empat pulau utama yang terhubung secara teknis membujur dari utara ke selatan yakni pulau-pulau Batam, Rempang, Galang dan Galang Baru dengan total panjang sekitar \pm 70 $\mathrm{km}$. Karenanya pulau ini dari segi penentuan jarak PLTN dari kawasan perkotaan lebih mudah, dan memungkinkan penyediaan tapak PLTN yang jauh dari penduduk, bila diinginkan 
demikian. Gambar 1 menunjukkan posisi kawasan Pulau Bintan - Barelang di perairan Selat Malaka. masa depan dengan: 1) sistem pembangkitan yang memenuhi aspek keekonomian seperti pembangkit berbahanbakar biaya rendah

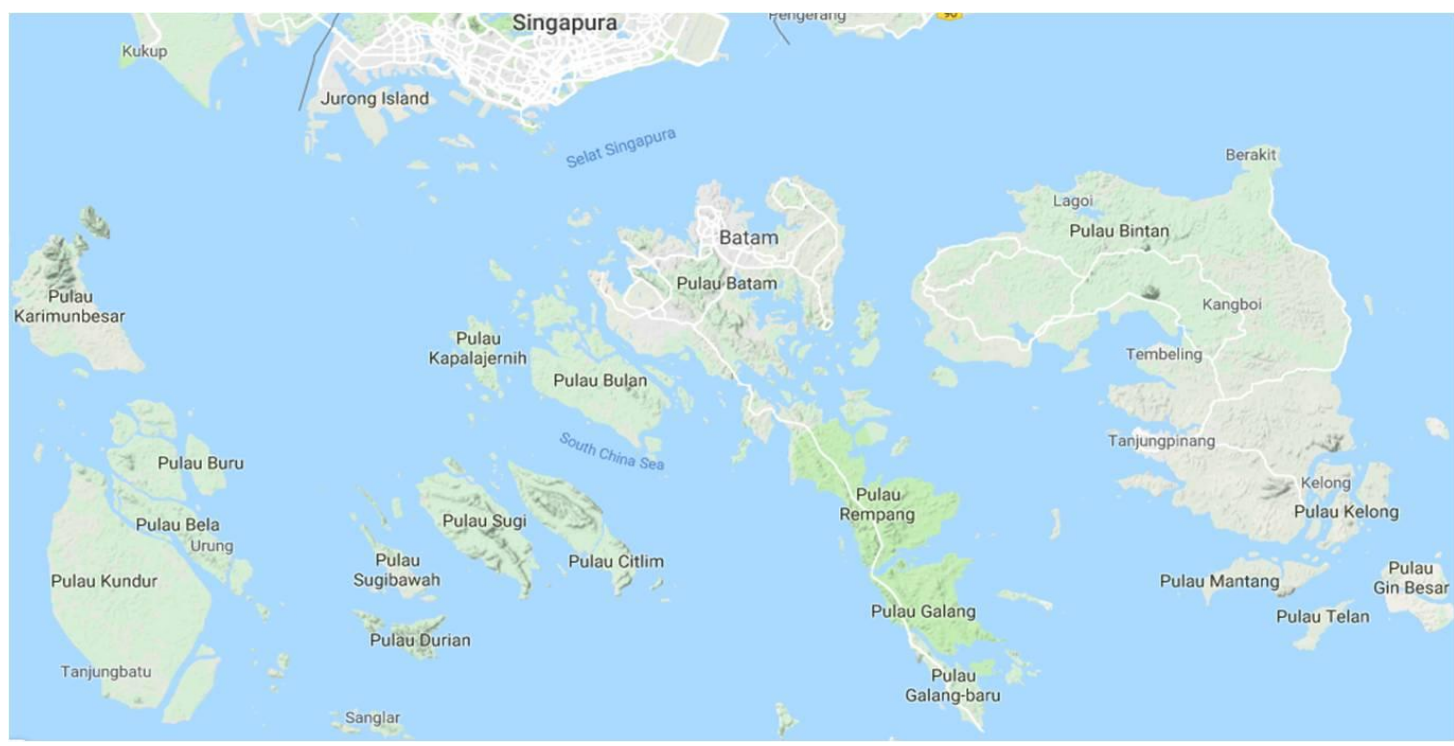

Gambar 1: Pulau Bintan - Barelang dan sekitarnya

Posisi Bintan - Barelang yang berada di salah satu kawasan paling sibuk di Asia Tenggara, di mana ada beberapa negara yang terlibat dalam kesibukan bisnis internasional, seperti Singapura, Malaysia dan Indonesia. Sedangkan Singapura adalah Negara pulau yang karena kelangkaan sumberdaya alam yang signifikan, aktifitas ekonomi dan bisnisnya bertumpu secara massif di sektor industri, perdagangan dan jasa[5]. Kondisi demikian membuat Singapura mengimport kebutuhan bahan-bahan alam dari luar negeri termasuk dari Indonesia.

Ketersediaan infrastruktur listrik yang efisien dan andal di Singapura telah berperan dalam aktifitas penduduk, dan juga telah merangsang pertumbuhan ekonomi regional kawasan Kepulauan Riau, dan Semenanjung Malaysia. Untuk memenuhi permintaan listrik yang terus meningkat, diperlukan investasi yang cukup besar di Kepulauan Riau setiap tahun. Sementara untuk masa yang akan datang, Singapura yang karena keterbatasan dalam sumberdaya alam dan luas wilayah, untuk memenuhi pertumbuhan permintaan listriknya, opsi lain yang dapat ditawarkan ke Singapura adalah tenaga listrik yang dibangkitkan di wilayah Indonesia[6].

Di sisi lain kawasan Bintan - Barelang memerlukan inovasi dalam pelayanan listrik di seperti nuklir, batubara dan gas; 2) sistem transmisi yang andal, stabil dan efisien[7].

Dengan memanfaatkan sumber energi baik nuklir maupun fosil untuk pembangkit listrik, serta sistem transmisi yang ekonomis, kawasan Bintan - Barelang mengandung aspek strategis di bidang kelistrikan.

\subsection{Energi dan kelistrikan Singapura}

Menilik ke negara tetangga Singapura sebagai wilayah dengan demand energi terbesar di kawasan tersebut, diperoleh fakta sebagai berikut. Konsumsi energi final Singapura, tumbuh pada tingkat rata-rata tahunan 6,3 persen dari 5,01 Mtoe pada 1990 menjadi 20,24 Mtoe pada tahun 2013. Selama periode yang sama, minyak merupakan sumber energi dominan, dengan 3,8 Mtoe dan 14,9 Mtoe dikonsumsi masing-masing pada tahun 1990 dan 2013. Sekitar 45,0 persen dari energi final negara tersebut dikonsumsi untuk penggunaan non-energi pada 2013, terutama sebagai bahan baku untuk industri petrokimia. Pada tahun 1990, 27 persen dari konsumsi energi final digunakan di sektor transportasi, meskipun pangsanya dari total konsumsi energi final menurun lebih dari 45 persen, pada tahun 2013 hanya mencapai sekitar 14,6 persen[8].

Sebagai sebuah negara kota di atas sebuah pulau kecil, upaya peningkatan kapasitas pem- 
bangkit listrik Singapura tentunya mengalami keterbatasan dalam banyak hal. Pembangunan PLTN yang diwacanakan juga menghadapi masalah cukup serius. Meskipun PLTN dapat dikatakan aman, namun persyaratan yang harus dipenuhi dalam mitigasi bencana menemui hambatan geografis [9].

Hampir sama dengan Barelang, luas daratan Singapura adalah $720 \mathrm{~km}$ persegi. Sementara daratan Bintan + Barelang adalah $1340+715=2055 \mathrm{~km}$ persegi $( \pm 3$ kali luas Jakarta). Permintaan akan bensin, gas alam, dan diesel untuk kendaraan jalan raya di Singapura, dapat diasumsikan bahwa ketergantungan terutama pada laju pertumbuhan kendaraan[10][11][12].

Konsisten dengan target kuota kendaraan yang ditetapkan oleh Otoritas Transportasi Darat, pertumbuhan kendaraan tetap sebesar 0,5 persen dari 2012 sampai 2014, dan 0,25 persen dari 2015 dan seterusnya menurut BAU[13].

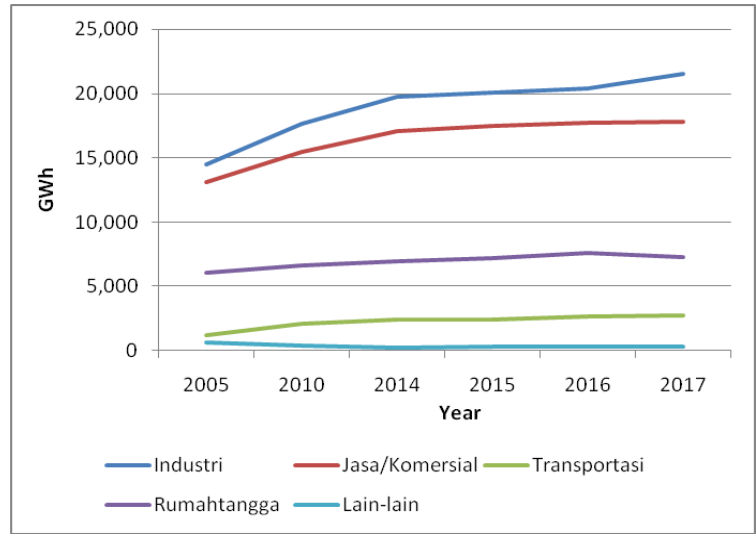

Gambar 2: Konsumsi Energi Listrik Singapura per sektor [14]

Permintaan listrik untuk sistem kereta MRT (Mass Rapid Transit) terutama didorong oleh perluasan panjang rel kereta api listrik, yang akan meningkat dari 153,2 $\mathrm{km}$ menjadi $328,3 \mathrm{~km}$ pada 2030, tingkat pertumbuhan rata-rata tahunan (AAGR) 1,02 persen per tahun[8]. Perluasan jaringan rel MRT akan mengurangi ketergantungan Singapura pada bahanbakar minyak dan gas pada sektor transportasi, namun akan membutuhkan peningkatan ketersediaan energi listrik sebagai penggantinya. Selain itu proyeksi ke depan jumlah kendaraan pribadi berbasis lisrtrik akan meningkat lebih tajam di negara industri tersebut. Gambar 2 menunjukkan data historis konsumsi listrik Singapura per sektor[14].

Di bawah BAU, pangsa minyak dalam konsumsi energi final Singapura diproyeksikan naik menjadi 81,4 persen pada tahun 2020, dan akan turun menjadi 76,9 persen pada tahun 2040. Penurunan ini terutama disebabkan oleh pertumbuhan tinggi dalam penggunaan gas alam, yang akan meningkat dari pangsanya 6,4 persen pada 2013 menjadi 8,1 persen pada 2040. Pangsa listrik dalam konsumsi energi final akan berkurang menjadi sekitar 1 - 2,5 persen pada 2020 dan naik menjadi 14,8 persen pada 2040[8]. Gambar 3 menunjukkan Proyeksi Permintaan Energi Listrik Singapura hingga tahun 2029[12].

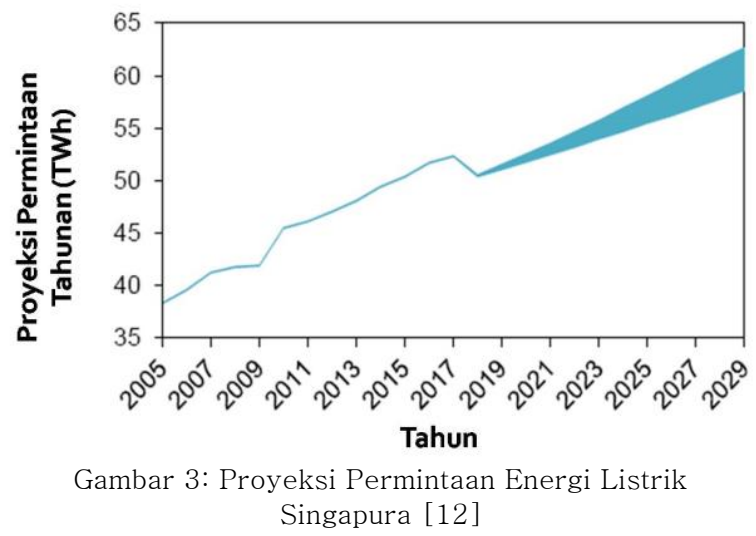

Diasumsi bahwa pertumbuhan kendaraan turun lebih lanjut, menjadi 0,2 persen pada 2017 dan seterusnya. Tidak ada upaya mitigasi karbon yang dikenakan untuk penggunaan listrik dalam sistem MRT, karenanya di sini APS1 tetap serupa dengan BAU[8]. Dari tahun ke tahun konsumsi listrik dan permintaan daya listrik menunjukkan peningkatan seperti tampak pada Tabel 1 .

Dari data historis, permintaan sistem kelistrikan Singapura telah meningkat dari sekitar 39 TWh pada 2006 menjadi sekitar 52 TWh pada 2016 dengan laju partumbuhan majemuk tahunan (compound annual growth rate, CAGR) sebesar 2,7\%. Permintaan beban puncak sistem tumbuh dari 5.624 MW menjadi 7.149 MW pada periode yang sama dengan CAGR sebesar 2,4\%[12], Permintaan sistem tahunan dan permintaan puncak sistem ini diproyeksikan akan tumbuh pada CAGR 1,3 1,9\% dari 2018 hingga 2028 (lihat Gambar 1 dan 2). Ini memperhitungkan berbagai faktor, termasuk perubahan populasi dan suhu, dan 
tingkat pertumbuhan Produk Domestik Bruto (PDB) yang diproyeksikan[12].

Tabel 1: Proyeksi beban puncak Singapura[12]

\begin{tabular}{cc} 
Tahun & Beban Puncak (MW) \\
\hline 2019 & $7460-7550$ \\
2020 & $7560-7690$ \\
2021 & $7670-7850$ \\
2022 & $7780-8010$ \\
2023 & $7890-8170$ \\
2024 & $7990-8330$ \\
2025 & $8100-8510$ \\
2026 & $8220-8680$ \\
2027 & $8330-8850$ \\
2028 & $8440-9010$ \\
2029 & $8560-9170$ \\
\hline
\end{tabular}

Singapura juga membutuhkan sejumlah pembangkit baru sebagai pengganti pembangkit lama yang harus pensiun dan perlunya penambahan kapasitas terpasang karena pertumbuhan permintaan. Hingga saat ini jenis dominan yang digunakan adalah pembangkit berbahan bakar gas.

\subsection{ASEAN Power Grid (APG)}

Perhimpunan Bangsa-Bangsa Asia Tenggara (ASEAN) telah memprioritaskan integrasi energi untuk meningkatkan keamanan energi kawasan. Untuk tujuan ini pembangunan infrastruktur listrik dianggap penting untuk memungkinkan perdagangan listrik di pasar terpadu. Manfaat jaringan listrik skala besar tersebut adalah peningkatan fleksibilitas ke pasar energi. Jaringan yang saling tersambung membantu keseimbangan antara kebutuhan dan penyediaan listrik melalui perdagangan antar wilayah maupun negara[15].

ASEAN Power Grid (APG) merupakan program unggulan yang diamanatkan pada tahun 1997 oleh pemimpin pemerintahan ASEAN di bawah Visi ASEAN 2020[16]. APG terdiri dari 16 proyek interkoneksi seperti yang tercantum dalam Tabel 2. Proyek ini diharapkan meluas dari bilateral menjadi subregional dengan tujuan akhir mencapai sistem yang terintegrasi secara total. Upaya mengamankan pasokan listrik adalah sangat penting untuk mempercepat pertumbuhan ekonomi negara berkembang di Asia Tenggara. Kebutuhan listrik kawasan diproyeksikan tumbuh sebesar $43 \%$ antara tahun 2010 dan 2035 yang lebih tinggi dari pertumbuhan di Asia dan Pasifik[17].
Dalam skema pembangunan APG, yang pertama kali dilakukan adalah persyaratan bilateral lintas batas, kemudian diperluas ke basis sub-regional, dan akhirnya ke sistem regional terintegrasi, untuk meningkatkan perdagangan listrik lintas batas[8].

Tabel 2: Jaringan ASEAN Power Grid[28]

\begin{tabular}{|c|c|}
\hline Koneksi & Operasi Komersial \\
\hline 1) Peninsular Malaysia - Singapore & 2018 \\
\hline \multicolumn{2}{|l|}{ 2) Thailand - Peninsular Malaysia } \\
\hline - Sadao - Bukit Keteri & Existing \\
\hline - Khlong Ngae - Gurun & Existing \\
\hline - Su Ngai Kolok - Rantau Panjang & 2015 \\
\hline - Khlong Ngae - Gurun (2nd Phase) & 2016 \\
\hline 3) Sarawak - Peninsular Malaysia & $2015-2021$ \\
\hline 4) Sumatra - Peninsular Malaysia & 2017 \\
\hline 5) Batam - Singapore & $2015-2017$ \\
\hline 6) Sarawak - West Kalimantan & 2015 \\
\hline 7) Philippines - Sabah & 2020 \\
\hline \multicolumn{2}{|l|}{ 8) Sarawak - Sabah - Brunei Darussalam } \\
\hline - Sarawak - Sabah & 2020 \\
\hline - Sarawak - Brunei Darussalam & $2012-2016$ \\
\hline \multicolumn{2}{|l|}{ 9) Thailand - Lao PDR } \\
\hline - Roi Et 2 - Nam Theun 2 & Existing \\
\hline $\begin{array}{l}\text { - Sakon Nakhon } 2 \text { - Thakhek - } \\
\text { Theun Hinboun (Expansion) }\end{array}$ & Existing \\
\hline - Mae Moh 3 - Nan - Hong Sa & 2015 \\
\hline - Udon Thani 3 - Nabong & 2018 \\
\hline $\begin{array}{l}\text { - Udon - Ratchathani } 3 \text { Pakse - Xe } \\
\text { Pian Xe Namnoy }\end{array}$ & 2018 \\
\hline - Khon Kaen 4 - Loei 2 - Xayaburi & 2019 \\
\hline - Thailand - Lao PDR (New) & $2015-2023$ \\
\hline 10) Lao PDR - Viet Nam & $2011-2016$ \\
\hline 11) Thailand - Myanmar & $2016-2025$ \\
\hline 12) Viet Nam - Cambodia (new) & 2017 \\
\hline 13) Lao PDR - Cambodia & 2016 \\
\hline 14) Thailand - Cambodia (new) & $2015-2020$ \\
\hline 15) East Sabah - East Kalimantan & 2020 \\
\hline 16) Singapore - Sumatra & 2020 \\
\hline
\end{tabular}

Posisi Kawasan Bintan - Barelang ke depannya akan menjadi lebih penting bagi pertumbuhan. Karena berada di jalur lalu lintas laut internasional maka Selat Malaka menjadi kawasan ini ekonomi dan bisnis yang ramai. Tingginya aktivitas ekonomi kawasan ini tampak pula pada penjualan listriknnya yang didominasi oleh sektor bisnis seperti ditunjukkan pada Tabel 3. 
Tabel 3: Penjualan Listrik Batam Tahun 2016[29]

\begin{tabular}{lrr} 
Golongan Tarif & \multicolumn{1}{c}{$\begin{array}{c}\text { Penjualan } \\
\text { (MWh) }\end{array}$} & \multicolumn{1}{c}{$\begin{array}{c}\text { Pendapatan } \\
\text { (juta Rp) }\end{array}$} \\
\hline Rumah Tangga & 63.703 & 578.872 \\
Industri & 52.788 & 603.504 \\
Bisnis & 106.114 & 1.251 .873 \\
Sosial & 4.853 & 44.884 \\
Pemerintah & 3967 & 65.373 \\
Umum & 1.394 & 104.260 \\
\hline Jumlah & 2.328 .190 & 2.648 .765
\end{tabular}

Melihat posisi geografisnya kawasan Barelang akan memiliki potensi sebagai pusat pengembangan eneri listrik di kawasan regional. Dalam hal ini akan dibutuhkan pengembangan sistem transmisi yang lebih besar dan lebih kuat berupa sistem yang melayani transmisi antara pulau untuk interkoneksi secara integral dengan wilayah sekitarnya regional. Sistem ini dapat berupa HVAC maupun HVDC yang memilki kapasitas dan efisiensi yang memadai. Secara umum, untuk jarak transmisi kabel laut laut sepanjang $50 \mathrm{~km}$ atau lebih, transmisi HVDC lebih ekonomis daripada transmisi HVAC. Dari segi perkembangannya kini HVDC telah menjadi teknologi yang mapan dan dapat diandalkan. [5]

\section{$2.3 \quad$ Kondisi terkini}

Bright PLN Batam menetapkan kebijakan pengelolaan pembangkit demi tercapainya keandalan, yaitu dengan disusunnya Pedoman Tata Kelola Pembangkit. Pedoman tersebut digunakan sebagai acuan standar pelaksanaan pengelolaan pembangkit baik pembangkit sendiri maupun mitra/IPP. Secara singkat, program pengelolaan pembangkit dibedakan menjadi lima program pokok yaitu: [18] rencana pembangkitan, manajemen keandalan, manajemen operasi, manajemen pemeliharaan dan manajemen energi primer. Untuk kota Tanjung Pinang tenaga listrik dipasok dari PLTD Air Raja, PLTD Sukaberenang, PLTMG Tokojo, PLTU sewa dan transmisi dari sistem Batam melalui transmisi dan kabel laut Batam - Bintan[19]. Dengan beroperasinya kabel laut $150 \mathrm{kV}$ Batam - Bintan maka sistem Batam - Bintan telah menjadi satu kesatuan sistem tenaga listrik, seperti ditunjukkan pada Gambar 4.

Daerah administratif yang juga berkembang pesat di Kepulauan Riau adalah Kabupa- ten Karimun yang dipasok dari Sistem Tanjung Balai Karimun. Daya sistem tersebut berasal dari PLTD Bukit Carok dan PLTU Tanjung Balai Karimun. Sedangkan pasokan listrik untuk kota Tanjung Pinang dipasok dari PLTD Air Raja, PLTD Sukaberenang, PLTMG Tokojo, PLTU sewa dan transfer dari sistem Batam melalui transmisi dan kabel laut Batam Bintan. Dengan beroperasinya kabel laut 150 $\mathrm{kV}$ Batam-Bintan maka sistem Batam-Bintan telah menjadi satu sistem tenaga listrik[20].

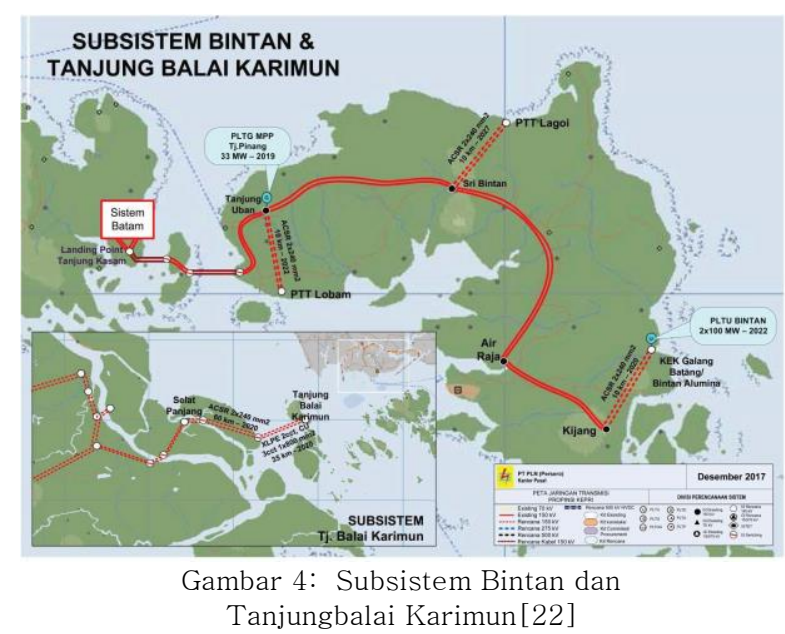

Ini diperkuat lagi dengan beberapa daerah di Kepulauan Riau (Batam, Bintan dan Karimun) yang tengah diupayakan sebagai pilot project pengembangan Kawasan Ekonomi Khusus (KEK) melalui kerjasama dengan Pemerintah Singapura[21].

Sementara itu PLTU Bintan 2x100 yang dijadwalkan beroperasi pada tahun 2022, sebagian dayanya akan dikirim ke Pulau Batam untuk memenuhi permintaan beban yang semakin tinggi[22].

\subsection{Opsi pengembangan sistem kelistrikan}

Untuk sektor ekonomi intensitas permintaan tenaga listrik relatif lebih tinggi, sehingga penambahan kapasitas masih terus diperlukan. Ada beberapa opsi yang dapat dikembangan untuk penambahan kapasitas tenaga listrik di Kawasan Bintan - Barelang, antara lain PLTU Batubara, PLT Gas, PLT Nuklir, PLT Biomass, PLT Angin, PLT Biomass, dsb. Dari berbagai jenis pembangkit tersebut masing-masing ada keunggulan dan kekurangannya. Namun untuk skala industri, pembangkit dengan biaya bahanbakar rendah 
paling ekonomis, karena demand energi pada sektor industri cenderung berada pada level beban dasar.

Pertimbangan untuk pengembangan kawasan Barelang di bidang tenaga listrik tidak terlepas dari perencanaan ke depan Kota Batam sebagai bagian kawasan yang sibuk dalam aktifitas ekonomi yang berbasis pada industri, perdagangan dan jasa. Karena alasan posisi geografis pertumbuhan kebutuhan listrik untuk Bintan - Barelang lebih tinggi daripada kawasan lain sekitarnya.

\section{PEMBAHASAN HASIL}

\subsection{Kelayakan PLTN}

Perkembangan kawasan Bintan - Barelang dan sekitarnya merupakan fenomena aspek geografis yang strategis di jalur perdagangan internasional. PLTN dapat memproduksi listrik dalam skala besar tanpa memproduksi emisi karbon, SOx, NOx dan partikulat ke udara. Jika di suatu pulau dibangun PLTN atau pembangkit jenis lain berskala besar, maka listriknya dapat dikirim ke pulau lain yang berdekatan langsung dengan transmisi HVAC sebagaimana kurva tegangan dibangkitkan. Namun bila dikirim ke pulau lain yang cukup jauh (misalnya $60 \mathrm{~km}$ atau lebih), maka pengiriman daya dapat dilakukan dengan sistem transmisi HVDC (High Voltage Direct Current) setelah melalui converter AC ke DC.

Jika suatu pulau yang membutuhkan listrik tidak ekonomis untuk memiliki pembangkit sendiri, maka pulau tersebut perlu dikaji apakah dapat dipasok dengan sistem transmisi HVDC yang lisriknya dapat bersumber dari berbagai jenis pembangkit, termasuk PLTN dari pulau lain. Transmiusi HVDC perlu menjadi kata kunci karena dapat mengatasi kendala kestabilan di dalam hal transmisi daya.

Di sisi lain pertumbuhan permintaan listrik di Pulau Bintan sebagai pulau kecil penghasil bauksit utama mambutuhkan peningkatan kapasitas terpasang. Dengan kecukupan tenaga listrik pulau ini seyogyanya tidak mengekspor bauksit ke luar negeri, melainkan dapat memproses bauksit sampai alumunium yang nilai tambahnya meningkat sekitar 13 kali lipat.
Kawasan Barelang tentunya juga akan membutuhkan peningkatan kapasitas terpasang karena semakin tingginya aktifitas jasa dan industri. Jarak antara Pulau Bintan ke Pulau Batam hanya $\pm 8 \mathrm{~km}$. Banyak wilayah di Indonesia termasuk Kepulauan Riau selama ini dipasok dengan listrik bertenaga diesel yang biaya produksi listriknya sangat tinggi sehingga menguras banyak dana subsidi, dan tak tersedianya energi listrik untuk meningkatkan nilai tambah sumberdaya hasil tambang. Untuk mengurangi beban subsidi, pembangkit diesel di wilayah terpencil (beban rendah) dan didominasi oleh penggunaan rumahtangga hanya dioperasikan dalam jumlah jam terbatas, biasanya antara pukul 17.00 sampai pukul 22.00, atau lebih kurang selama lima jam setiap hari, ke depannya perlu disambungkan ke jaringan listrik utama. Dengan demikian pemanfaatan listrik tidak hanya untuk penerangan, sehingga ketersediaan listrik untuk aktifitas ekonomi tercapai.

Kawasan Bintan - Barelang ke depan akan menjadi demand listrik intensitas tinggi karena aktifitasnya di bidang industri, jasa dan perdagangan sehingga membutuhkan pengembangan sistem kelistrikan dalam kapasitas yang jauh lebih besar. Pulau Bintan sendiri merupakan kawasan pertambangn bauksit yang membutuhkan pengembangan smelter sebagai fasilitas industri peleburan dan pemurnian hasil tambang yang selama ini langsung diekspor ke luar negeri.

Rencana kedepan penggantian pembangkit berbahanbakar diesel dengan pembangkit berbahan bakar yang relatif murah dan berskala industri seperti batu bara dan nuklir diperlukan untuk meningkatkan daya kompetisi, efektifitas dan efisiensi ekonomi nasional. Sementara dari aspek nuklir, ada beberapa kriteria yang sesuai untuk suatu lokasi tapak PLTN yang terpenuhi oleh Kawasan Bintan Barelang, yakni aspek geologi, pertumbuhan demand, mitigasi bencana, dan aspek biaya.

\subsection{Kriteria Tapak PLTN}

Ditinjau dari segi aspek kriteria seleksi tapak PLTN untuk wilayah Kepulauan Riau, kawasan Batam - Barelang mempunyai prospek yang baik. Dari segi geologi wilayah ini tergolong stabil dan risiko rendah bencana 
gempa[23]. Juga berada di sekitar beban listrik yang sedang berkembamg dengan pertumbuhan relatif tinggi, dekat dengan negara dengan aktifitas ekonomi tinggi di sektor jasa dan industri. Hal ini memperkuat penjelasan bahwa dari segi permintaan pasar energi, bila biaya produksi cukup bersaing maka nilai jual di wilayah sekitar cukup menjanjikan. Kriteria umum yang ditentukan untuk tapak PLTN biasanya mencakup antara lain: lingkungan dan penduduk, kegempaan, banjir dan tsunami.

\subsubsection{Lingkungan dan penduduk}

Prinsip umum dalam penentuan lokasi pembangkit listrik tenaga nuklir adalah memiliki fasilitas di daerah berpenduduk jarang dan jauh dari pusat populasi besar [24].

Terkait dengan hal populasi salah satu masalah yang dihadapi Singapura dalam implementasi tenaga nuklir adalah karena tingginya kepadatan penduduk di wilayah negara kota, yang tidak memungkinkan adanya area steril diatas radius $5 \mathrm{~km}$. Sementara area evakuasi yang disyaratkan tidak terpenuhi oleh teknologi yang tersedia hingga saat ini[9].

Penduduk kota Batam menurut data tahun 2016 tercatat sebanyak 1.236.399 jiwa yang tersebar di 11 kecamatan, atau kerapatan rata-rata sebesar 1729 jiwa/km2[25]. Sedangkan Pulau Bintan yang terhimpun dalam satu kabupaten penduduk berjumlah 157.927 jiwa, atau dengan kerapatan 118 jiwa/km2[26]. Dengan fakta ini Pulau Bintan maupun wilayah Kota Batam sendiri kepadatan penduduknya jauh lebih rendah bila dibanding dengan Singapura yang kepadatan penduduknya 8.339 jiwa/km2[13]. Sementara itu wilayah Kota Batam penduduk terkonsentrasi di Pulau Batam sedangkan tiga pulau lainnya yakni Rempang, Galang dan Galang Baru penduduk masih sangat jarang.

Kepadatan populasi yang lebih rendah di kawasan PLTN dibutuhkan karena membantu dalam pengurangan risiko dosis radiasi terhadap populasi, dan memastikan implementasi yang efektif jika terjadi kecelakaan karena lebih mudah diimplementasikan pada kelompok populasi yang lebih kecil.

\subsubsection{Kegempaan}

Wilayah Indonesia sendiri banyak dilalui jalur gempa mulai Aceh melintas di sepanjang Bukit Barisan di Pulau Sumatera, terus ke sepanjang Pulau Jawa yang lebih dominan bagian tengah dan selatan, Nusa tenggara, Sulawesi, Maluku dan terus ke Papua.

Gambar 5 menginformasikan jalur gempa di Kawasan asia Tenggara hingga Papua Nugini. Sementara belahan dan pesisir timur Pulau Sumatra, Kepulauan Riau meliputi Pulau Bintan dan Barelang, dan Seluruh wilayah Pulau Kalimantan ditunjukkan sebagai wilayah bebas gempa. Dengan demikian dari aspek kegempaan kawasan Bintan - Barelang merupakan kawasan yang layak sebagai tapak PLTN.

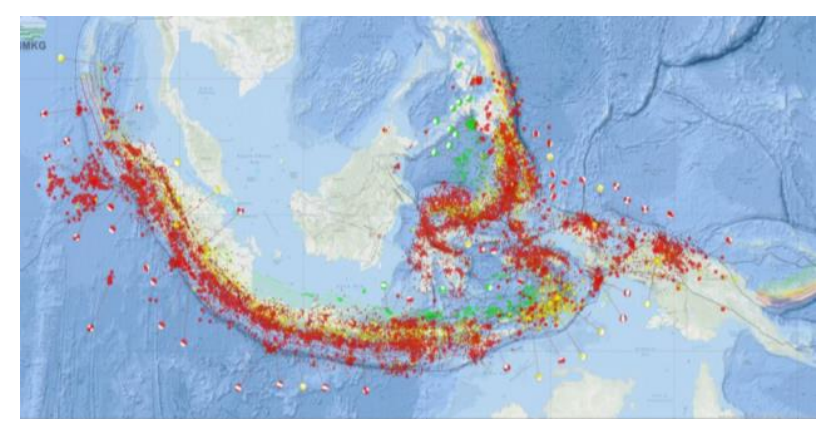

Gambar 5: Sebaran gempa bumi di Indonesia [23]

\subsubsection{Banjir dan tsunami}

Banjir adalah salah satu fenomena alam yang penting untuk pertimbangan tapak. Oleh karena itu, sejarah banjir di lokasi lalu dikumpulkan. Tapak tidak boleh mengalami perendaman apa pun. Untuk lokasi pantai, tingkat kemiringan tapak yang aman diperkirakan dari pasang naik tertinggi bersama dengan gelombang badai dan gelombang naik akibat tsunami, dan lain lain[24].

Di kawasan Bintan - Barelang, dilihat dari risiko banjir yang berasl dari air hujan relatif mudah diatasi pada tapak terpilih, sedangkan melihat pada geografis kepulauan banjir tsunami juga relatif aman karena rendahnya potensi gempa bumi baik di darat maupun di laut[27].

\subsection{Analisis SWOT}

Dari uraian di atas disusun analisis SWOT, yaitu analisis atas kekuatan (strengths), kelemahan (weaknesses), peluang 
(opportunities), dan ancaman (threats) dalam bentuk tabel yang merangkum hasil penilaian Aspek Geografis Tapak PLTN di Kawasan Bintan - Barelang seperti ditunjukkan pada Tabel 6 berikut.

Tabel 4: Analisis SWOT

\begin{tabular}{|c|c|c|}
\hline & Unsur yang menguatkan & $\begin{array}{l}\text { Unsur yang } \\
\text { melemahkan }\end{array}$ \\
\hline $\begin{array}{l}\text { Aspek } \\
\text { Internal }\end{array}$ & $\begin{array}{l}\text { Kekuatan } \\
\text { - Posisi geografis dan } \\
\text { demand energi listrik } \\
\text { menjanjikan } \\
\text { - Aspek tapak baik } \\
\text { - Biaya per satuan energi } \\
\text { lebih rendah } \\
\text { - Menguntungkan untuk } \\
\text { jangka panjang } \\
\text { - Ketersediaan listrik } \\
\text { yang andal }\end{array}$ & $\begin{array}{l}\text { Kelemahan } \\
\text { - Butuh biaya investasi } \\
\text { tinggi } \\
\text { - Butuh waktu lama } \\
\text { untuk pengembalian } \\
\text { modal } \\
\text { Strategi } \\
\text { Kecermatan dalam } \\
\text { Evaluasi Ekonomi } \\
\text { Proyek }\end{array}$ \\
\hline $\begin{array}{l}\text { Aspek } \\
\text { Eksternal }\end{array}$ & $\begin{array}{l}\text { Peluang } \\
\text { - Peningkatan kapasitas } \\
\text { terpasang untuk skala } \\
\text { industri } \\
\text { - Tidak ada pesaing yang } \\
\text { signifikan } \\
\text { - Pengembangan industri } \\
\text { smelter } \\
\text { - ASEAN Power Grid, } \\
\text { sebagai gerbang } \\
\text { memasuki pasar } \\
\text { regional Asia Tenggara }\end{array}$ & $\begin{array}{c}\text { Ancaman } \\
\text { - Menyebabkan utang } \\
\text { jangka panjang } \\
\text { - Bunga pinjaman } \\
\text { jangka panjang } \\
\text { Strategi } \\
\text { Pemanfaatan peluang } \\
\text { secara maksimal }\end{array}$ \\
\hline
\end{tabular}

\section{KESIMPULAN}

Kawasan Bintan - Barelang merupakan kawasan strategis nasional yang bersinggunggan secara langsung dengan kawasan jasa dan industri negara jiran Singapura dan Malaysia. Kawasan ini memiliki potensi pengembangan sistem kelistrikan yang dapat berperan secara regional memasuki pasar regional Asia Tenggara atas komitmen kerjasama negara terkait dalam proyek ASEAN Power Grid. Selain memiliki aspek geografis yang strategis, Bintan - Barelang juga memiliki kondisi geologi yang memadai untuk pengembangan pembangkit listrik berskala besar, diantaranya adalah PLTN. Beberapa syarat dan ketentuan umum yang dibutuhkan sebagai tapak PLTN relative mudah terpenhi di kawasan ini, antara lain dari aspek demand energi listrik, geologi, hidrologi, oseanografi dan mitigasi bencana.

\section{DAFTAR PUSTAKA}

[1] -- Dinas Kebudayaan Provinsi Kepulauan Riau, "Sejarah Batam," pp. 1-6, 2016.

[2] --, "Sejarah Kota Batam." PKNU Kota Batam, Batam, pp. 1-5, 2019

[3] --, "Data Sensus PDRB Kota Batam 2010-2017," Kota Batam - Provinsi Kepulauan Riau KP 29464, 2019.

[4] --, "Keputusan Presiden Republik Indonesia Nomor 41 Tahun 1973 Tentang Daerah Industri Pulau Batam,” no. 1. Republik Indonesia, 1973.

[5] Hawksford, "What makes the Singapore economy tick?” pp. 1-7, 2019 .

[6] S. Ibrahim, "ASEAN Power Grids Interconnection Projects for Energy Efficiency and Security of Supply," Regional Energy Trade Workshop, Manila, 2014.

[7] --, RUPTL PLN 2017 - 2026, no. 1415. PT PLN (Persero).

[8] L.T.S. Allan and J. Tao, "Singapore Country Report, Chapter 15, September 2016," ERIA Research Project Report 2015-5, Jakarta: ERIA, pp.297-322., 2016.

[9] O. Siong, "Current nuclear energy technology "not suitable for use in Singapore." CNA, Singapore, 2012.

[10] --, "Kondisi Sosial dan Politik Singapura di Masa Awal Kemerdekaan,” 2017, p. Bab II.

[11] --, Singapore Energi Statistics 2015. Singapore: Energy Market Authority, 2015.

[12] --, Singapore Electricity Market Outlook (SEMO) 2018, 3rd ed., no. October. Singapore: Energy Market Authority, 2018.

[13] --, Singapore in Figures 2018. Singapore: Department of Statistics Singapore, 2018.

[14] --, Singapore Energy Statistics 2018. Singapore: Energy Market Authority.

[15] --, "Southeast Asia Energy Outlook 2015," International Energy Agency (IEA), 75739 Paris Cedex 15 France, 2015.

[16] M. Gallery, E. Meeting, and M. Meeting, "Memorandum of Understanding on the ASEAN Power Grid,” pp. 1999-2004, 2019.

[17] E. Liun, "Peran strategis pulau batam di bidang energi di kawasan regional asia tenggara," in Prosiding Seminar Nasional Teknologi Energi Nuklir 2016 Batam 4-5 Agustus 2016, 2016, pp. 185-192.

[18] --, Statistik PLN 2014, no. 2701. Jakarta: PT PLN (Persero).

[19] --, "Generation and Transmission Business Unit." Bright PLN Batam, Batam, pp. 1-3, 2019.

[20] R. Usaha and P. T. Listrik, “2015 - 2024,” pp. 2015-2024, 2015.

[21] PT Perusahaan Listrik Negara (Persero), 
“Keputusan Menteri ESDM No. 1415 K/20/MEM/2017 Tentang Rencana Usaha Penyediaan Tenaga Listrik ( RUPTL ) PLN 20172026," vol. 2026, no. 29 Maret 2017, 2017.

[22] --, RUPTL PT PLN (Persero). Jakarta: PT PLN (Persero), 2018.

[23] --, "Berita Mitigasi Gempabumi; Kerja Bersama, untuk Indonesia Tangguh.” BMKG, Jakarta Pusat, DKI Jakarta 10720, pp. 1-6, 2019.

[24] U. S. P. Verma, "Site Selection Criteria for Nuclear Power Plants and Evaluation of Site Specific Design Basis Earthquake Parameters," no. January. Nuclear Power Corporation of India Limited, Mumbai, 2019.

[25] --, “Kota Batam Dalam Angka 2018”, BPS Kota Batam, 2019.

[26] V. Misi, "Jumlah Penduduk 2010 - 2017 Unduh Data Tabel Beranda Tabel,” p. 2020, 2020.

[27] --, Guideline for Site Selection for Nuclear Power Plant. Selangor Darul Ehsan, Malaysia: Atomic Energy Licencing Board, Ministry of Science, Technology and Innovation, 2011.

[28] --, Energy Outlook for Asia and the Pacific, no. October. 2013.

[29] --, Statistik PLN 2016. Jakarta: Sekretariat Perusahaan PT PLN (Persero), 2017. 